\title{
APPLICATION OF THE INDUCTIVELY COUPLED PLASMA-MASS SPECTROMETRY (ICP-MS) METHOD IN ZINK ANALYSIS
}

\author{
Nabilah Bilqis ${ }^{1{ }^{*}}$, Erni Sulistiawati ${ }^{2)}$ dan Miftakh Nur Rahman ${ }^{3)}$ \\ ${ }^{1)}$ Analisis Kimia, Institut Pertanian Bogor, Jl Kumbang No 14, Bogor, 16128, Indonesia; \\ ${ }^{2}$ Sekolah Vokasi, Institut Pertanian Bogor, Jl. Kumbang No.14, Bogor, 16128, Indonesia; \\ ${ }^{3)}$ PT Prodia Widyahusada Tbk, Jl Kramat Raya No 150, Jakarta, 10410, Indonesia.
}

\section{ARTICLE INFO}

Article history:

Received 14 Jun 2021,

Revised 12 Jan 2022,

Accepted 16 Jan 2022

Available online 24 Jan 2022

Keywords:

$$
\begin{aligned}
\checkmark & \text { defisiensi zink } \\
\checkmark & \text { inductively coupled } \\
& \text { plasma-mass } \\
& \text { spectrometry (icp-ms) } \\
\checkmark & \text { zink }
\end{aligned}
$$

*corresponding author: Nabilahbilqis99@gmail.com Phone: +6287770416363

https://doi.org/10.31938/jsn.v $12 \mathrm{i} 1.321$

\begin{abstract}
Zinc is a nutrient that affects cell growth, helps the body's metabolism, activates $T$ cells (T lymphocytes), cell regeneration, and repairs body tissues. Zinc in the body undergoes a process of excretion every day, therefore daily intake of zinc needs to be considered to maintain the amount of zinc in the body in a normal amount. This study aimed to obtain information on the application of the Inductively coupled plasma-mass spectrometry (ICP$M S)$ method to determine the concentration of zinc in the serum of pregnant women. The application of Inductively coupled plasma-mass spectrometry (ICP-MS) method in zinc analysis provided the advantages of a minimal sample volume requirement with higher instrument sensitivity, fast retention time and had a concentration detection limit of up to parts per billion ( $\mathrm{ppb}$ ). Analysis of the zinc concentration in the serum of pregnant women using the ICP-MS method showed 80\% serum with a concentration below the reference value, $13.3 \%$ normal and $6.7 \%$ a concentration higher than the WHO reference value.
\end{abstract}

\section{ABSTRAK}

\section{Aplikasi Metode Inductively Coupled Plasma-Mass Spectrometry (ICP-MS) Dalam Analisis Zink}

Zink adalah salah satu jenis zat gizi yang sangat berpengaruh terhadap pertumbuhan sel, mengaktifkan sel T (limfosit T), regenerasi sel, dan membantu metabolisme tubuh. Zink di dalam tubuh setiap harinya mengalami proses ekskresi oleh karena itu asupan harian zink perlu diperhatikan untuk menjaga jumlah zink di dalam tubuh tetap dalam jumlah yang normal. Penelitian ini bertujuan untuk mendapatkan informasi penggunaan metode Inductively coupled plasma-mass spectrometry (ICP-MS) untuk menentukan konsentrasi zink dalam serum ibu hamil. Penggunaan metode ICP-MS dalam analisis zink memberikan keuntungan berupa kebutuhan volume sampel minimal dengan sensitivitas alat lebih tinggi, waktu retensi yang cepat serta memiliki batas limit deteksi konsentrasi hingga bagian per triliun (ppt). Analisis konsentrasi zink dalam serum ibu hamil dengan metode ICP-MS menunjukan $80 \%$ serum dengan konsentrasi dibawah nilai rujukan, $13,3 \%$ normal dan $6,7 \%$ konsentrasi yang lebih tinggi dibandingkan nilai rujukan menurut WHO.

Kata kunci : defisiensi zink, inductively coupled plasma-mass spectrometry (icp-ms), zink

\section{PENDAHULUAN}

Mineral esensial merupakan mineral yang dibutuhkan dalam proses fisiologis makhluk hidup dalam pembentukan organ atau membantu kerja enzim. Mineral esensial dalam tubuh memiliki beberapa unsur yang terbagi menjadi dua golongan, yaitu mineral mikro dan mineral makro. Mineral makro dibutuhkan oleh tubuh dalam jumlah besar seperti kalsium, kalium, natrium, fosfor dan magnesium sedangkan mineral mikro dibutuhkan oleh tubuh dalam jumlah sedikit seperti zink, kobalt, tembaga, iodin, besi dan mangan (Arifin, 2008).

Zink adalah salah satu zat gizi yang berpengaruh terhadap pertumbuhan sel, mengaktifkan sel $\mathrm{T}$ (limfosit $\mathrm{T}$ ), regenerasi sel, membantu metabolisme tubuh, dan memperbaiki jaringan tubuh. Zink di dalam tubuh setiap harinya mengalami proses ekskresi oleh karena itu asupan harian zink perlu diperhatikan untuk menjaga jumlah zink di dalam tubuh tetap dalam jumlah yang normal karena di dalam tubuh tidak 
terdapat mekanisme khusus dalam penyimpanan zink (Simbolon, 2019). Kebutuhan zink meningkat pada masa kehamilan, laktasi dan anak-anak. Defisiensi zink pada ibu hamil dapat menyebabkan tidak optimalnya pertumbuhan dan fungsi imunitas janin serta terganggunya fungsi kognitif (Anggraheni, 2015). Salah satu parameter yang dapat digunakan untuk menetapkan konsentrasi zink di dalam tubuh sebagai indikator defisiensi zink antara lain konsentrasi zink dalam serum darah. Konsentrasi zink di dalam serum adalah parameter yang paling sering digunakan untuk menetapkan kadar zink seseorang, karena mudah dilakukan dan hasilnya akurat (Gibson, 2005). Konsentrasi zink dalam serum dapat diukur menggunakan Inductively coupled plasma-mass spectrometry (ICP-MS). ICP-MS memiliki kelebihan yaitu dapat mengukur kadar multi unsur dalam waktu yang bersamaan, jumlah sampel yang dibutuhkan sedikit dan mempunyai batas deteksi (limit detection) yang rendah yaitu hingga tingkat nanogram (Rukihati \& Saryati, 2006). Penelitian ini bertujuan untuk mendapatkan informasi penggunaan metode Inductively coupled plasmamass spectrometry (ICP-MS) untuk mengukur konsentrasi zink ( $\mathrm{Zn})$ dalam serum darah ibu hamil.

\section{BAHAN DAN METODE}

\section{Bahan dan Alat}

Bahan-bahan yang dipergunakan yaitu Sampel Serum sebanyak 15 sampel, n- Butanol, ICP multi-element standard solution IV $10 \mathrm{mg} / \mathrm{L}$, Serum Control lyophilised, ultra-pure water, Alkohol 70\%, $\mathrm{HNO}_{3} 2 \%, \mathrm{HNO}_{3} 6 \%$, Tabung ICP $6 \mathrm{~mL}$, Triton X-100, Amonia 25\%, Padatan EDTA, Standar Indium $1000 \mathrm{mg} / \mathrm{L}$, Standar Merkuri 1000 mg/L, Tabung Darah bertutup biru

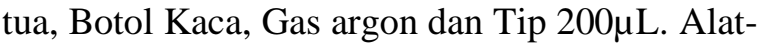
alat yang digunakan yaitu ICP-MS (Agilent 7700X), Fumehood, Mikropipet $200 \mu \mathrm{L}$ dan 10 $\mathrm{mL}$, Pipet AutoRep E, Vortex, Labu ukur $100 \mathrm{~mL}$ dan $1000 \mathrm{~mL}$, Sudip, Neraca analitik (Ohaus PA214), Rak tabung, Sonikator, microtube vortex dan Sentrifuse.

\section{Metode}

Pembuatan Diluen. Ultra-pure water sebanyak $500 \mathrm{~mL}$ dimasukkan ke dalam labu ukur $1000 \mathrm{~mL}$ kemudian EDTA ditimbang sebanyak 37 miligram dan ditambahkan ke dalam labu ukur. Larutan tersebut ditambahkan Triton X-100 sebanyak $700 \mu \mathrm{L}$ dan Amonia 25\% sebanyak 105 $\mu \mathrm{L}$. Larutan kemudian ditera dengan ultra-pure water dan dihomogenkan. Larutan disonikasi selama $1 \mathrm{jam}$. Prosedur pembuatan larutan standar merkuri $10 \mathrm{mg} / \mathrm{L}$ yaitu sebanyak $1 \mathrm{~mL}$ larutan stok merkuri $1000 \mathrm{mg} / \mathrm{L}$ dipipet ke dalam labu ukur $100 \mathrm{~mL}$, kemudian ditera dengan diluen dan dihomogenkan. Prosedur pembuatan larutan standar indium $10 \mathrm{mg} / \mathrm{L}$ yaitu sebanyak $1 \mathrm{~mL}$ larutan stok indium $1000 \mathrm{mg} / \mathrm{L}$ dipipet ke dalam labu ukur $100 \mathrm{~mL}$, kemudian ditera dengan $\mathrm{HNO}_{3}$ 6\% dan dihomogenkan.

Pembuatan Larutan Standar dan Kontrol Serum. Larutan Deret Standar dibuat sebanyak 8 level dengan pengenceran bertahap. Larutan Stok Standar 8 dibuat dengan dicampurkan ICP multi element standard solution $10 \mathrm{mg} / \mathrm{L}$ sebanyak $5000 \mu \mathrm{L}$, standar merkuri $10 \mathrm{mg} / \mathrm{L}$ sebanyak 500 $\mu \mathrm{L}$ dan diluen sebanyak $4500 \mu \mathrm{L}$ ke dalam botol kaca, kemudian larutan tersebut divortex sampai homogen. Larutan Stok Standar 7 hingga 1 dibuat secara seri dengan faktor pengenceran sebanyak 4 kali yaitu $1 \mathrm{~mL}$ standar ditambahkan $3 \mathrm{~mL}$ diluen. Pembuatan deret standar dilakukan dengan cara masing - masing standar dipipet sebanyak $100 \mu \mathrm{L}$, kemudian ditambahkan $20 \mu \mathrm{L}$ n-butanol dan diluen sebanyak $1880 \mu \mathrm{L}$. Larutan deret Standar 0 dibuat dengan dicampurkan diluen sebanyak $1980 \mu \mathrm{L}$ dan n-butanol sebanyak $20 \mu \mathrm{L}$ sedangkan blanko digunakan $\mathrm{HNO}_{3} 2 \%$. Larutan kontrol serum dihomogenkan dengan microtube vortex selama 5 menit kemudian, larutan dipipet sebanyak $200 \mu \mathrm{L}$ dimasukkan ke dalam tabung ICP kemudian ditambahkan diluen sebanyak $1800 \mu \mathrm{L}$ setelah itu larutan divortex. Kontrol serum dibuat dua kali ulangan. Sampel darah pasien sebanyak 15 orang yang masing - masing disimpan di dalam tabung bertutup biru tua yang berisikan EDTA bebas logam. Sampel darah kemudian disentrifuse dengan kecepatan sebesar 3000 rpm selama 15 menit. Serum yang didapatkan dipipet sebanyak $200 \mu \mathrm{L}$ ke dalam vial ICP, kemudian ditambahkan diluen sebanyak $1800 \mu \mathrm{L}$. Larutan sampel kemudian divortex agar homogen.

\section{HASIL DAN PEMBAHASAN}

Sampel yang digunakan untuk penentuan zink adalah serum sebanyak 15 sampel, serum diperoleh dengan cara pemisahan dengan sentrifuse 3000 rpm selama 15 menit yang berasal dari sampel darah tanpa antikoagulan. Serum yang didapatkan dipipet sebanyak $200 \mu \mathrm{L}$, 
kemudian dimasukkan ke dalam vial ICP. Sampel serum darah ditambah diluen sebanyak $1800 \mu \mathrm{L}$ dan divortex agar homogen. Larutan diluen berisikan EDTA sebanyak 37 miligram, $700 \mu \mathrm{L}$ Triton X-100, $105 \mu \mathrm{L}$ Amonia 25\% dan ultrapure water. Larutan diluen tersebut berfungsi untuk menjaga protein dan lemak tetap dalam larutan sampel serta Triton X-100 yang merupakan surfaktan juga berfungsi untuk meningkatkan kelarutan protein dalam sampel (Levi et al., 2018). Metode ICP-MS adalah teknik yang paling efektif untuk mengukur trace elements dan mineral dalam sampel biologis. Jumlah volume sampel biologis yang sedikit menjadi salah satu keterbatasan dalam analisis tetapi ICP-MS dapat mengatasi masalah tersebut. Metode ICP-MS banyak dikembangkan untuk pemeriksaan dalam bahan biologis seperti darah, plasma, urin dan rambut. Metode ICP-MS mampu mengkuantifikasi 27 hingga 32 elemen secara bersamaan dalam matriks biologis (Goulle et al., 2005).

Tabel 1. Hasil pengukuran konsentrasi zink dalam serum darah

\begin{tabular}{cc}
\hline Sampel & Konsentrasi Zink $(\mu \mathrm{g} / \mathrm{dL})$ \\
\hline 1 & 123 \\
2 & 62 \\
3 & 76 \\
4 & 98 \\
5 & 51 \\
6 & 63 \\
7 & 55 \\
8 & 29 \\
9 & 43 \\
10 & 58 \\
11 & 64 \\
12 & 66 \\
13 & 63 \\
14 & 80 \\
15 & 72 \\
\hline
\end{tabular}

Penentuan konsentrasi zink di dalam tubuh sangat diperlukan karena zink memiliki peranan esensial dalam fungsi tubuh. Konsentrasi zink di dalam serum paling sering digunakan sebagai parameter uji dalam menetapkan keadaan konsentrasi zink seseorang karena mudah dilaksanakan dan hasil yang didapatkan akurat sedangkan metode ICP-MS banyak digunakan untuk penentuan multi element dalam sampel serum manusia karena efisien, sensitivitas tinggi, memiliki kemampuan analisis isotop, hasil analisis yang didapatkan mencapai presisi dan akurasi yang tinggi untuk analisis isotop, serta waktu analisis yang dibutuhkan cepat (Abduljabbar et al., 2019). Hasil pengukuran konsentrasi zink dalam serum dapat dilihat pada Tabel 1.

Keuntungan pengukuran zink mengguna-kan ICP-MS adalah sensitivitas alat lebih tinggi dan memiliki batas limit deteksi konsentrasi hingga bagian per triliun (ppt). Selain itu, ICP-MS dapat mengukur konsentrasi logam secara multi element dalam analisis dengan waktu yang cepat dan jumlah sampel yang dibutuhkan untuk analisis lebih sedikit dibandingkan dengan AAS (Tyler \& Yvon, 2003).

Berdasarkan hasil pengukuran konsentrasi zink pada Tabel 1 sampel serum pasien ibu hamil memiliki konsentrasi zink berkisar antara 29 $123 \mu \mathrm{g} / \mathrm{dL}$. Nilai rujukan konsentrasi zink dalam serum menurut world health organization (WHO) yaitu $80-110 \mu \mathrm{g} / \mathrm{dL}$. Berdasarkan nilai rujukan tersebut persentase hasil sampel yang dianalisis yaitu $80 \%$ memiliki konsentrasi lebih rendah dari nilai rujukan, $13,3 \%$ normal dan $6,7 \%$ memiliki konsentrasi lebih tinggi dari nilai rujukan. Hal ini menunjukkan bahwa sebagian besar pasien ibu hamil tersebut mengalami defisiensi zink atau kekurangan zink. Ibu hamil sangat rentan terhadap defisiensi zink karena jumlah zink pada ibu hamil relatif mengalami penurunan sebesar $35 \%$ yang terjadi akibat adanya perubahan hormon dan pembagian nutrisi dari ibu ke janin. Konsentrasi zink yang rendah pada ibu hamil dapat menyebabkan berkurangnya nutrisi dari ibu ke janin dan berdampak pada berkurangnya penyediaan gizi yang memadai untuk janin. Fungsi zink bagi ibu hamil yaitu mendukung perkembangan dan pertumbuhan janin sampai dengan masa balita dan anak-anak. Defisiensi zink selama kehamilan dapat menyebabkan keterlambatan tumbuh kembang pada janin karena berpengaruh terhadap sistem imun (Wijaksono et al., 2019). Defisiensi zink di dalam tubuh dapat disebabkan oleh beberapa faktor seperti kurangnya asupan zink, gangguan proses penyerapan zink, konsentrasi albumin dalam plasma, meningkatnya kebutuhan zink dalam tubuh dan ekskresi zink.

\section{KESIMPULAN}

Penggunaan metode Inductively coupled plasma-mass spectrometry (ICP-MS) dalam pengukuran zink memberikan keuntungan berupa 
kebutuhan volume sampel minimal dengan sensitivitas alat lebih tinggi, waktu pengukuran yang cepat serta memiliki batas limit deteksi konsentrasi hingga bagian per trilliun (ppt). Analisis konsentrasi zink dalam serum ibu hamil dengan metode ICP-MS menunjukkan $80 \%$ sampel serum memiliki konsentrasi lebih rendah dari nilai rujukan, $13,3 \%$ normal dan $6,7 \%$ konsentrasi yang lebih tinggi dibandingkan nilai rujukan menurut WHO.

\section{UCAPAN TERIMA KASIH}

Penulis mengucapkan terima kasih kepada staff - staff laboratorium Mass Spectrometry PT Prodia Widyahusada Tbk dalam membimbing, memfasilitasi dan mendukung penulis dalam menyelesaikan studi ini.

\section{DAFTAR PUSTAKA}

[WHO]. World Health Organization. (1996). Zinc: Trace Element In Human Nutrition And Health.Geneva : WHO

Abduljabbar, T., Sharp, B., Reid, H., Befroeid, N., Peto, T. dan Lengyel, I. (2019). Determination of $\mathrm{Zn}, \mathrm{Cu}$ and $\mathrm{Fe}$ in Human Patients Serum using Micro-Sampling ICP-MS and Sample Dilution. Talanta 204, 663-669

Anggraheni, N. (2015). Gambaran Kadar Serum Seng dan Z-Score TB/U pada Anak Usia 912 Tahun. (Skripsi). Universitas Diponegoro, Semarang, Indonesia

Arifin, Z. (2008). Beberapa Unsur Mineral Esensial Mikro Dalam Sistem Biologi Dan Metode Analisisnya. Jurnal Litbang Pertanian. 27(3), 99-105

Gibson, R. (2005). Principles Of Nutritional Assessment. New York(US), Oxford University Press

Goulle, J., Mahieu, L., Casterment, J., Neveu, N., Bonneau, L., Laine, G., Bouige, D., dan Lacroix, C. (2005). Metal And Metalloid Multi-Elementary ICP-MS In Whole Blood, Plasma, Urine And Hair. Forensic science international. 153, 39-44
Levi, M., Hjelm, C., Harari, F., dan Vahter, M. (2018). ICP-MS Measurement of Toxic and Essential Elements in Human Breast Milk. A Comparison of Alkali Dilution and Acid Digestion Sample Preparation Methods. Clinical Biochemistry. 53, 81-87

Rukihati \& Saryati. (2006). Analisis Cuplikan Lingkungan dan Bahan Geologi Dengan Inductively Coupled Plasma-Mass Spectrometry. Jurnal Sains Materi Indonesia. 8(1), 92-97

Simbolon, D. (2019). Intervensi Gizi Spesifik Pencegahan Stunting (Panjang Badan Pendek) Pada Ibu Menyusui Dan Anak Usia 0-24 Bulan. Surabaya, Indonesia: Media Sahabat Cendekia

Tyler, G. dan Yvon, J. (2003). ICP-OES, ICP-MS and AAS Techniques Compared. Horiba, $1-11$

Wijaksono, A., Rasyid, R., dan Mariko, R. (2019). Hubungan Kadar Zink dan Kenaikan Berat Badan Ibu Hamil dengan Berat Badan Bayi Lahir di RSUD Curup Kabupaten Rejang Lebong Propinsi Bengkulu. Majalah Kedokteran Andalas. 42(2), 56-61 